\title{
Analysis of the Fiscal Rule Index in EU Member States
}

\author{
Sabina Hodžić \\ University of Rijeka, Faculty of Tourism and Hospitality Management, Croatia \\ Emira Bečić \\ Ministry of Science, Education and Sports of the Republic of Croatia, Croatia
}

\section{Abstract}

Fiscal rules have been the centre of economic debate in European Union Member States. They indicate the direction in which policymakers aim to evolve public finances. In recent years the public finances of European Union Member States have been affected by two major changes in economic and institutional settings. These are the establishment of Economic and Monetary Union and progressive fiscal decentralisation in a significant number of European Union Member States. In order to support the fiscal decentralisation process European Union Member States need to have appropriate fiscal policy rules. They can stimulate policy coordination between different levels of government depending on their institutional coverage. The aim of this paper is to present an analysis of the fiscal rule index and fiscal rule strength index in European Union Member States, with special emphasis on Croatia. The Directorate-General for Economic and Financial Affairs methodology was used in analysing the fiscal rule index and fiscal rule strength index by type and government sectors in the period from 2003-2013 in European Union Member States. Based on our results, the fiscal rule index for Croatia, from the period 2003-2013, is continually on the rise from -1.01 in 2008 to a high 1.43 in 2013.

Keywords: public finances, fiscal policy, fiscal rule index, fiscal rule strength index, EU area

JEL classification: $\mathrm{H} 60, \mathrm{H} 87$

\section{Introduction}

EU Member States, including Croatia (since 01 July 2013), have a strong interest in fiscal policy rules, with the aim of reducing public sector deficits and public sector debts. According to Hallerberg et al. (2007) "interest in fiscal rules is a reaction to the experience in many countries of rapidly rising debt levels and unsustainable deficits in the 1970s and 1980s." (p. 339) After the 2007/2008 financial crisis, some regulations have been amended in the EU to strengthen EU's fiscal governance and to maintain sustainability of public finances. After these regulations, EU Member States introduced fiscal rules, independent fiscal councils and more stringent medium-term budgeting frameworks. The objectives of these fiscal rules are to curb the deficit bias of governments, lead to balanced public finances and to assure the financial markets about the medium term fiscal goals. According to Marneffe et al. (2010) "fiscal rules, whether quantitative or not, indicate the direction in which policymakers aim the public finances to evolve and the public sector's role in macroeconomic processes. It also provides a solution to the deficit bias problem that is caused by the governments' short-sightedness and the common pool problem." (p. 2)

Fiscal policy rules control targets for annual government deficits, debts or spending. The European Commission (2006) points to significant heterogeneity of 
national fiscal frameworks within the EU and suggests that "stronger" fiscal rules are conductive to sound public finances (and ultimately more efficient and growthenhancing economic policies). According to European Commission (2010) "domestic fiscal frameworks are defined as the set of elements that form national fiscal governance, i.e. the overall system of arrangements, procedures and institutions that underlines the planning and implementation of budgetary policies (p. 73).

Kopits and Symanski (1998) state that a fiscal rule is "a permanent constraint on fiscal policy, expressed in terms of a summary indicator of fiscal performance, such as the government budget deficits, borrowing debt or a major component thereof."The design of the appropriate fiscal framework depends on country-specific circumstances (Von Hagen 2006, Hallerberg et. al. 2007, 2009, Ljungman, 2008). In literature, there are several studies that try to evaluate the effectiveness of EU fiscal rules and the impact of EU fiscal rules on economic growth (Arestis et al. 2001, Warin 2005, Wyplosz 2006, Galli and Perotti 2003, Marinheiro 2004, Artis and Onorante 2006, Hein and Truger 2005, Savona and Viviani 2003, Soukiazis and Castro 2003, 2005). Sacchi and Salotti (2015) found that the aggressive use of discretionary fiscal policy, particularly of government consumption items, leads to higher volatility of output and, to a lesser extent, inflation. They find that the introduction of fiscal rules significantly affects the stabilisation function of fiscal policy. Castro (2011) provides evidence that, on average, growth is statistically higher in the period in which the fulfilment of the $3 \%$ criteria for the deficit started to be officially assessed. Reuter (2015) states that fiscal rules act as a kind of benchmark for policy makers, and the public, and even though they might be complied with only in half of the years, they still tilt fiscal policy towards numerical limits in times of non-compliance.

In this paper, the main aim is to present an analysis of the fiscal rule index (FRI) in the period from 2003-2013 and fiscal rule strength index (FRSI) in EU Member States, with special emphasis on Croatia in the period from 2008-2013. The goal of this paper is to stress the uncertainty and sensitivity of the fiscal rule index that arise from the fiscal rule coverage and criteria used in its construction. The value of the fiscal rule index has been critically reviewed, considering specific circumstances of the fiscal framework by countries and adopted fiscal rules.

\section{Methodology}

There are broad categories and types of numerical fiscal rules, i.e. budget balance, borrowing and debt rules, expenditure rules and revenue rules (European Commission 2006,p. 149).

According to the methodology applied in European Commission, Public Finances in the EMU - 2006 report, the measurement of the strength of fiscal rules is based on five criteria (p. 163):

- Criterion 1: statutory base of the rule;

- Criterion 2: nature of the body in charge of monitoring respect of the rule;

- Criterion 3: nature of the body in charge of enforcement;

- Criterion 4: enforcement mechanisms of the rule and

- Criterion 5: media visibility

The methodology was based on a previous work by Deroose et. al. (2005). The fiscal rule strength index is calculated for each rule by aggregating the scores. "The scores of the five criteria were first standardised to run between 0 and 1 . Then a random weights technique was used following the method used by Sutherland et al. (2005). This techniques uses 10000 sets of randomly generated weights to calculate the synthetic indicator in 10000 different ways. The random weights are drawn from a uniform distribution between zero and one and then normalised to sum to one. This 
measurement of strength of fiscal rules was combined with a measurement of the coverage by weighting the rule with the percentage share of the general government finances covered by the rule." (European Commission 2006, p. 164)

The fiscal rule index contains all the available information on national numerical fiscal rules. According to DG ECFIN (2007) "the characteristics of fiscal rules vary depending on the sub-sector to which they apply. Fiscal rules applying to higher levels of government are usually incorporated into a multi-annual budgetary framework whereas most rules applied to regional and local governments rely preponderantly on annual schemes." (p. 76)

\section{Data analysis and Results}

The fiscal rules database on domestic fiscal rules in force for EU Member States contains the time series from 1990 to 2013. The dataset covers all types of numerical fiscal rules (budget balance, debt, expenditure, and revenue rules) at all levels of government (central, regional, and local, general government, and social security). For the purpose of this paper, we analyse the data from 2008-2013 according to the type of the numerical fiscal rule (see Table 1) and the trend for fiscal rule index in the period 2003-2013. (Appendix 1)

\section{Table 1}

Fiscal rule strength index according to the type of the numerical fiscal rule, 2008 2013

\begin{tabular}{|c|c|c|c|c|c|c|c|}
\hline Country & Type' & 2008 & 2009 & 2010 & 2011 & 2012 & 2013 \\
\hline \multirow[t]{2}{*}{ Austria } & BBR & 6.92 & 6.92 & 6.92 & 7.5 & 8.81 & 8.81 \\
\hline & ER & - & 6.4 & 6.4 & 6.4 & 6.4 & 6.4 \\
\hline \multirow[t]{2}{*}{ Belgium } & BBR & 6.02 & 6.02 & 6.02 & 6.02 & 6.68 & 6.68 \\
\hline & ER & 7.57 & 7.57 & 7.57 & 7.57 & 7.57 & 7.57 \\
\hline \multirow[t]{3}{*}{ Bulgaria } & DR & 7.74 & 7.74 & 7.74 & 7.74 & 7.74 & 7.74 \\
\hline & ER & 4.72 & 4.72 & 4.72 & 4.72 & 5.72 & 5.72 \\
\hline & BBR & - & - & - & 5.24 & 7.06 & 7.06 \\
\hline Croatia & ER & - & - & - & 7.47 & 7.47 & 7.47 \\
\hline Cyprus & BBR & - & - & - & - & - & 6.52 \\
\hline \multirow[t]{2}{*}{ Czech Republic } & ER & 5.74 & 5.74 & 5.74 & 5.74 & 5.74 & 5.74 \\
\hline & $\mathrm{DR}$ & 6.6 & 6.12 & 6.12 & 6.12 & 6.12 & 6.12 \\
\hline \multirow[t]{3}{*}{ Denmark } & BBR & 5.88 & 5.88 & 5.88 & 5.88 & 5.88 & 5.88 \\
\hline & ER & 5.88 & 5.88 & 5.88 & 5.88 & - & - \\
\hline & $R R$ & 7.63 & 7.63 & 7.63 & - & - & - \\
\hline \multirow[t]{2}{*}{ Estonia } & BBR & 6.95 & 6.95 & 6.95 & 6.95 & 6.3 & 6.3 \\
\hline & DR & 6.67 & 6.67 & 6.67 & 6.67 & 5.05 & 6.67 \\
\hline \multirow[t]{4}{*}{ Finland } & BBR & 6.77 & 6.77 & 6.77 & 6.77 & 6.11 & 6.11 \\
\hline & DR & - & - & - & 6.11 & 6.11 & 6.11 \\
\hline & ER & 6.27 & 6.27 & 6.27 & 6.27 & 4.95 & 4.95 \\
\hline & $R R$ & 3.98 & 3.98 & 3.98 & 3.98 & 3.98 & 3.98 \\
\hline France & BBR & 7.73 & 7.73 & 7.73 & 7.73 & 7.73 & 7.73 \\
\hline
\end{tabular}

\footnotetext{
I BBR - budget balance rule; ER - expenditure rule; RR - revenue rule; DR - debt rule
} 


\begin{tabular}{|c|c|c|c|c|c|c|c|}
\hline Country & Type 1 & 2008 & 2009 & 2010 & 2011 & 2012 & 2013 \\
\hline & DR & 7.62 & 7.62 & 7.62 & 7.62 & 7.62 & 7.62 \\
\hline & ER & 4.71 & 4.71 & 7.33 & 7.33 & 7.33 & 7.33 \\
\hline & $R R$ & 6.27 & 7.62 & 7.62 & 7.62 & 7.62 & 7.62 \\
\hline \multirow[t]{2}{*}{ Germany } & BBR & 6.59 & 6.59 & 6.59 & 10 & 10 & 10 \\
\hline & ER & 5.87 & 5.87 & 5.87 & - & - & - \\
\hline Greece & BBR & - & - & - & - & 7.91 & 7.91 \\
\hline \multirow[t]{2}{*}{ Hungary } & BBR & 5.05 & - & - & - & - & - \\
\hline & $\mathrm{DR}$ & - & 5.05 & 5.05 & 5.05 & 5.05 & 5.05 \\
\hline \multirow[t]{3}{*}{ Ireland } & BBR & 5.25 & 5.25 & 5.25 & 5.25 & 5.25 & 5.25 \\
\hline & DR & - & - & - & - & - & 8.23 \\
\hline & ER & 5.72 & 5.72 & 5.72 & 5.72 & 5.72 & 5.72 \\
\hline \multirow[t]{2}{*}{ Italy } & BBR & 6.78 & 6.78 & 6.78 & 6.78 & 6.78 & 6.78 \\
\hline & ER & 6.14 & 6.14 & 6.14 & 6.14 & 6.8 & 7.2 \\
\hline \multirow[t]{3}{*}{ Latvia } & BBR & - & - & - & - & - & 7.21 \\
\hline & DR & 6.07 & 6.07 & 6.07 & 6.07 & 6.07 & 6.07 \\
\hline & $R R$ & 6.67 & 6.67 & 6.67 & 6.67 & 6.67 & 6.67 \\
\hline \multirow[t]{4}{*}{ Lithuania } & BBR & 6.81 & 6.81 & 6.81 & 6.81 & 6.81 & 6.81 \\
\hline & DR & 6.7 & 6.7 & 6.7 & 6.7 & 8.02 & 8.02 \\
\hline & ER & 8.3 & 8.3 & 8.3 & 8.3 & 6.98 & 6.98 \\
\hline & RR & 7.62 & 7.62 & 7.62 & 7.62 & 6.3 & 6.3 \\
\hline \multirow[t]{3}{*}{ Luxembourg } & BBR & 6.41 & 6.41 & 6.41 & 6.41 & 6.41 & 6.41 \\
\hline & $\mathrm{DR}$ & 3.98 & 3.98 & 3.98 & 3.98 & 3.98 & 3.98 \\
\hline & ER & 4.66 & 4.66 & 3.3 & 3.3 & 3.98 & 3.98 \\
\hline Malta & - & - & - & - & - & - & - \\
\hline \multirow[t]{2}{*}{ Netherlands } & ER & 5.64 & 5.64 & 5.64 & 5.64 & 6.3 & 6.3 \\
\hline & $R R$ & 6.01 & 6.01 & 6.01 & 6.01 & 6.01 & 6.01 \\
\hline \multirow[t]{3}{*}{ Poland } & BBR & - & - & - & 7.24 & 6.58 & 6.58 \\
\hline & DR & 9.05 & 9.05 & 9.05 & 9.05 & 9.05 & 9.05 \\
\hline & ER & - & - & - & 6.81 & 7.47 & 7.47 \\
\hline \multirow[t]{2}{*}{ Portugal } & BBR & 4.78 & 4.78 & 4.78 & 4.78 & 5.74 & 5.74 \\
\hline & $\mathrm{DR}$ & - & - & - & - & - & 7.07 \\
\hline \multirow[t]{2}{*}{ Romania } & BBR & 5.05 & 5.05 & 5.05 & 5.05 & 5.05 & 5.05 \\
\hline & DR & 5.72 & 5.72 & 5.72 & 5.72 & 5.72 & 5.72 \\
\hline \multirow[t]{3}{*}{ Slovakia } & BBR & 5.44 & 6.64 & 6.64 & 6.64 & 6.64 & 6.64 \\
\hline & $\mathrm{DR}$ & 6.01 & 6.01 & 6.01 & 6.01 & 6.01 & 6.01 \\
\hline & ER & 8.04 & 8.04 & 8.04 & 8.04 & 7.38 & 7.38 \\
\hline \multirow[t]{2}{*}{ Slovenia } & $\mathrm{DR}$ & 7.62 & 7.62 & 7.62 & 7.62 & 6.96 & 6.96 \\
\hline & ER & - & - & 5.51 & 5.51 & - & - \\
\hline \multirow[t]{3}{*}{ Spain } & BBR & 6.66 & 6.66 & 6.66 & 6.66 & 8.77 & 8.77 \\
\hline & $\mathrm{DR}$ & 5.74 & 5.74 & 5.74 & 5.74 & 5.74 & 5.74 \\
\hline & ER & - & - & - & 5.72 & 6.92 & 6.92 \\
\hline Sweden & BBR & 6.66 & 6.66 & 6.66 & 6.66 & 6.66 & 6.66 \\
\hline
\end{tabular}




\begin{tabular}{|c|l|c|c|c|c|c|c|}
\hline Country & Type $^{1}$ & $\mathbf{2 0 0 8}$ & $\mathbf{2 0 0 9}$ & $\mathbf{2 0 1 0}$ & $\mathbf{2 0 1 1}$ & $\mathbf{2 0 1 2}$ & $\mathbf{2 0 1 3}$ \\
\hline & ER & 6.84 & 6.84 & 8.02 & 8.02 & 8.02 & 8.02 \\
\hline \multirow{2}{*}{ United Kingdom } & BBR & - & 7.36 & 7.62 & 7.62 & 7.62 & 7.62 \\
\cline { 2 - 8 } & DR & 8.14 & - & 8.02 & 7.62 & 7.62 & 7.62 \\
\hline
\end{tabular}

Source: European Commission, DG ECFIN, Fiscal Rule Database, http://ec.europa.eu/economy_finance/db_indicators/fiscal_governance/fiscal_rules/index en.htm

Data in Table 1 show that all EU Member States, including Croatia, have some type of numerical fiscal rule. Almost all EU Member States (except Croatia, Netherlands and Slovenia) have budget balance rules. Countries that apply all types of numerical fiscal rules are Finland, France and Lithuania.

The design of the appropriate fiscal framework by countries depends on countryspecific circumstances as evidenced by the rules introduced in the periods 20052008 and 2009-2012 by country or that will enter into force after 31December 2013. Countries whose main target/constraint is structural balance as \% of GDP are Austria, Germany, France, Ireland, Italy, Luxembourg, Latvia, Portugal and Slovakia. Targets of all of these countries are in general government. An interesting situation can be found in Croatia where targets are debt ceiling in terms of debt/GDP ratio in central government and social security and nominal expenditure in \% of GDP in general government. Based on the fiscal rule strength index for each rule, a comprehensive time-varying composite fiscal rule index ${ }^{2}$ for each Member State was constructed by summing up all fiscal rule strength indices in force in respective EU Member States, including Croatia (Appendix 1). From the data in Appendix 1, we can observe that in the period 2003-2013, countries with a positive growth of FRI are Austria, Belgium, Bulgaria, Germany, Greece, Denmark, Spain, Croatia, Hungary, Luxembourg, Latvia, Netherlands, Poland, Sweden, Slovakia and the United Kingdom. Countries with a negative growth of FRI are Cyprus, Czech Republic, Ireland, Italy, Malta, Romania and Slovenia. The FRI for Croatia, from the period 2003-2013, is continually on the rise from -1.01 in 2008 to a high 1.43 in 2013. This proves that Croatia is continuously and systematically improving its budget balance in the current economic situation.

\section{Conclusion}

Fiscal policy rules control targets for annual government deficits, debts or spending. The objective of fiscal rules is to enhance budgetary discipline and to foster policy coordination between different levels of government, depending on their institutional coverage. A European fiscal framework was established with the Maastricht Treaty and the Stability and Growth Pact.

Our analysis of FRSI and FRI has shown that all EU Member States, including Croatia, have some type of numerical fiscal rule. Countries that apply all types of numerical fiscal rules are Finland, France and Lithuania, while all other countries (except Croatia, Netherlands and Slovenia) have budget balance rules. In the observed period, 2003-2013, most of the analysed EU Member States recorded a positive growth of FRI. In 2013, countries with the highest FRI were France and

2See more about FRI at:

http://ec.europa.eu/economy_finance/db_indicators/fiscal_governance/fiscal_rules/index en.htm The FRI is calculated using an index for strength of fiscal rules that gives an equal weight to the five criteria entering in the calculation of the indicator. 
Germany. The FRI for Croatia, in the period 2003-2013, is continually on the rise from 1.01 in 2008 to a high 1.43 in 2013. That proves that Croatia is continuously and systematically improving its budget balance in the current economic situation.

To boost economic recovery and maintain fiscal deficit within the $3 \%$, EC is introducing a new mechanism of control known as the Macroeconomic Imbalance Procedures (The MIP procedure) and is tightening the control of macroeconomic imbalance. Our recommendation for future research would be to examine fiscal rule effectiveness across government levels in all European Union Member States and beyond, considering significant heterogeneity of national fiscal frameworks within the EU and specific circumstances of the fiscal framework by countries and adopted fiscal rules.

\section{References}

1. Arestis, P. et al. (2001), "An alternative stability pact for the European Union", Cambridge Journal of Economics, Vol. 25, pp. 113-130.

2. Artis, M., Onorante, L. (2006), "The economic importance of fiscal rules", CEPR discussion paper 5684, Centre for Economic Policy Research, London.

3. Castro, V. (2011), "The impact of the European Union fiscal rules on economic growth" Journal of Macroeconomics, Vol. 33, pp. 313-326.

4. Deroose, S., Moulin, L., Wierts, P. (2006), "National Expenditure Rules and Expenditure Outcomes: Empirical Evidence for EU Member States", Wirtschaftspolitische Baletter, Vol. 1, pp. 27-42.

5. DG ECFIN (2007), "Fiscal rules in the EU at national level: experiences and lessons", European Commission, pp. 59-82.

6. European Commission (2006), "Public Finances in EMU", European Economy 3, Luxembourg: Office for Official Publications of the European Communities.

7. European Commission (2010), "Public Finances in EMU", European Economy 4, Luxembourg: Office for Official Publications of the European Communities.

8. European Commission - DG ECFIN (2015), "Fiscal rule database", available at: http://ec.europa.eu/economy_finance/db_indicators/fiscal_governance/fiscal_rules/ind ex_en.htm (accessed June 10 th 2015)

9. Galli, J., Perotti, R. (2003), "Fiscal policy and monetary integration in Europe", NBER working paper no. 9773.National Bureau of Economic Research, Cambridge.

10. Hallerberg, M. et al. (2007), "The design of fiscal rules and forms of governance in European Union countries", European Journal of Political Economy, Vol. 23, pp. 338-359.

11. Hallerberg, M. et al. (2009), "Fiscal Governance in Europe", Cambridge, Cambridge University Press.

12. Hein, E., Truger, A. (2005), "European Monetary Union: nominal convergence, real divergence and slow growth?", Structural Change and Economic Dynamics, Vol. 16, pp. 7-33.

13. Kopits, G., Symanski, S. (1998), "Fiscal Policy Rules", IMF Occasional paper 162, International Monetary Fund, Washington.

14. Ljungman, G. (2008), "Expenditure Ceilings - A Survey", working paper no. 08/282, International Monetary Fund, Washington.

15. Marinheiro, C. (2004), "Has the Stability and Growth Pact Stabilized?", available at: http://www4.fe.uc.pt/carlosm/research/pdf/sgpdec04_cmarinheiro.pdf (accessed June $\left.10^{\text {th }}, 2015\right)$.

16. Marneffe, W. et al. (2010), "The Impact of Fiscal Rules on Public Finances: Theory and Empirical Evidence for the Euro Area", working paper no. 3303, CESifo Group Munich.

17. Reuter, W.H. (2015), "National numerical fiscal rules: Not complied with, but still effective?", European Journal of Political Economy, Vol. 39, pp. 67-81.

18. Sacchi, A., Salotti, S. (2015), "The impact of national fiscal rules on the stabilisation function of fiscal policy", European Journal of Political Economy, Vol. 37, pp. 1-20. 
19. Savona, P., Viviani, C., (2003), "The impact of stability and growth pact on real economic growth: automatic mechanism or policy discretion?", Review of Economic Conditions in Italy, Vol. 2, pp. 263-279.

20. Soukiazis, E., Castro, V. (2003), "The impact of the Maastricht criteria and the Stability and Growth Pact on growth and unemployment in Europe", CEUNEUROP discussion paper no. 15, Faculty of Economics, Universidade de Coimbra.

21. Soukiazis, E., Castro, V. (2005), "How the Maastricht criteria and Stability and Growth Pact affected real convergence in the European Union: a panel data analysis", Journal of Policy Modeling, Vol. 27, pp. 385-399.

22. Sutherland, D. et al. (2005), "Fiscal Rules for Sub-Central Governments: Design and Impact", OECD working paper no.1, Organization for Economic Co-Operation and Development, Paris.

23. Von Hagen, J. (2006), "Fiscal rules and fiscal performance in the European Union and Japan", Monetary and Economic Studies, Vol. 24 No. 1, pp. 25-60.

24. Warin, T. (2005), "The hidden structural features of the fiscal rule: a European saga", International Advances in Economic Research, Vol. 11, pp. 29-38.

25. Wyplosz, C. (2006), "European Monetary Union: the dark sides of a major success", Economic Policy, Vol. 21, pp. 207-261.

Appendix 1

Fiscal rule index by EU Member States in the period 2003-2013

\begin{tabular}{|c|c|c|c|c|c|c|c|c|c|c|c|}
\hline & 2003 & 2004 & 2005 & 2006 & 2007 & 2008 & 2009 & 2010 & 2011 & 2012 & 2013 \\
\hline AT & 0.2934 & 0.2934 & 0.1732 & 0.1732 & 0.1732 & 0.1231 & 0.7631 & 0.7631 & 0.8574 & 1.0740 & 1.0740 \\
\hline BE & 0.0511 & 0.0511 & 0.0511 & 0.0511 & 0.0511 & 0.0511 & 0.0511 & 0.0511 & 0.0511 & 0.0855 & 0.0855 \\
\hline BG & 0.7833 & 0.7833 & 0.8033 & 1.3520 & 1.3520 & 1.3520 & 1.3520 & 1.3520 & 1.7774 & 2.0658 & 2.0658 \\
\hline CY & -1.0147 & -1.0147 & -1.0147 & -1.0147 & -1.0147 & -1.0147 & -1.0147 & -1.0147 & -1.0147 & -1.0147 & 0.3838 \\
\hline$C Z$ & -1.0147 & -0.4177 & 0.2125 & 0.2125 & 0.2125 & 0.2125 & -0.0505 & -0.0505 & -0.0505 & -0.0505 & -0.0505 \\
\hline DE & 0.3975 & 0.3975 & 0.3975 & 0.3975 & 0.3975 & 0.3975 & 1.1160 & 0.7106 & 1.1920 & 1.1920 & 3.1964 \\
\hline DK & 1.3983 & 1.3983 & 1.3983 & 1.3983 & 1.5037 & 1.5037 & 1.5037 & 1.5037 & 0.7196 & 1.5301 & 1.5301 \\
\hline $\mathrm{EE}$ & 0.9492 & 0.9492 & 0.9492 & 0.9492 & 0.9492 & 0.9492 & 0.9492 & 1.0816 & 1.0816 & 0.7330 & 1.0816 \\
\hline EL & -1.0147 & -1.0147 & -1.0147 & -1.0147 & -1.0147 & -1.0147 & -1.0147 & -1.0147 & -1.0147 & 0.8707 & 0.8707 \\
\hline ES & 1.5884 & 1.5884 & 1.5884 & 1.4203 & 1.4203 & 1.4203 & 1.4203 & 1.4203 & 2.3747 & 3.0457 & 3.0457 \\
\hline FI & 1.0334 & 1.0334 & 1.0334 & 1.0334 & 1.0358 & 0.6102 & 0.1906 & 0.1906 & 0.4364 & 0.3152 & 0.3152 \\
\hline FR & -0.0043 & -0.0043 & -0.0043 & 0.4425 & 0.4425 & 0.5778 & 0.9355 & 0.7218 & 1.4162 & 1.4162 & 3.5396 \\
\hline HR & -1.0147 & -1.0147 & -1.0147 & -1.0147 & -1.0147 & -1.0147 & 0.3104 & 0.3104 & 1.4270 & 1.4270 & 1.4270 \\
\hline HU & -0.7874 & -0.7874 & -0.7874 & -0.7874 & 0.4158 & 0.4158 & 0.1628 & 0.1628 & 0.1628 & 0.9464 & 0.9464 \\
\hline IE & -0.9892 & -0.7668 & -0.7668 & -0.7668 & -0.7668 & -0.7668 & -0.7668 & -0.7668 & -0.7668 & -0.7756 & 2.7502 \\
\hline IT & 0.0221 & 0.0221 & 0.0221 & 0.0221 & -0.1947 & -0.2159 & -0.2676 & -0.2255 & -0.2151 & -0.2134 & -0.1949 \\
\hline LT & -0.0218 & -0.0218 & -0.0218 & 0.0423 & 0.0423 & 0.6852 & 0.6852 & 0.6852 & 0.6852 & 0.7065 & 0.7065 \\
\hline LU & 0.9167 & 1.8405 & 1.8405 & 1.8405 & 1.8405 & 1.8405 & 1.8405 & 1.1998 & 1.1998 & 1.2093 & 1.6949 \\
\hline LV & 0.0126 & 0.0126 & 0.0126 & 0.0126 & 0.0126 & 0.0126 & 0.0126 & 0.0126 & 0.0126 & 0.0126 & 2.4459 \\
\hline MT & -1.0147 & -1.0147 & -1.0147 & -1.0147 & -1.0147 & -1.0147 & -1.0147 & -1.0147 & -1.0147 & -1.0147 & -1.0147 \\
\hline NL & 1.0020 & 1.0020 & 1.0020 & 1.0020 & 1.0020 & 1.0020 & 1.0020 & 1.0020 & 1.0020 & 1.0746 & 1.0746 \\
\hline PL & 1.0882 & 1.0882 & 1.0882 & 1.9412 & 1.9412 & 1.0882 & 1.5338 & 1.5338 & 1.9039 & 1.8602 & 1.6823 \\
\hline PT & -0.1517 & -0.1517 & -0.1517 & -0.1517 & -0.0967 & -0.0967 & -0.0967 & -0.0967 & -0.0967 & 0.0646 & 1.7486 \\
\hline RO & -0.5867 & -0.5867 & -0.5867 & -0.5867 & -0.5867 & -0.5867 & -0.5867 & -0.5867 & -0.5867 & -0.5867 & -0.5867 \\
\hline SE & 2.0081 & 2.0081 & 2.0081 & 2.0081 & 2.1271 & 2.1271 & 2.1271 & 2.2847 & 2.2847 & 2.2847 & 2.2847 \\
\hline SI & 0.3590 & 0.3590 & 0.3590 & 0.3590 & 0.3590 & 0.3590 & 0.3590 & 0.3759 & 0.4865 & -0.8127 & -0.8127 \\
\hline SK & 0.2325 & 0.2325 & 0.2325 & 0.2325 & 0.2325 & 0.2325 & 0.2078 & 0.2078 & 0.2078 & 2.4719 & 2.4719 \\
\hline UK & 1.8600 & 1.8600 & 1.8600 & 1.8600 & 1.8600 & 1.8600 & -1.0147 & 1.5178 & 1.5024 & 1.5024 & 1.5024 \\
\hline
\end{tabular}

Source: European Commission, DG ECFIN, Fiscal Rule Database, http://ec.europa.eu/economy_finance/db_indicators/fiscal_governance/fiscal_rules/index en.htm 


\section{About the authors}

Sabina Hodžić, Ph.D., works as a Senior Assistant at the Department of Public Finance at the Faculty of Tourism and Hospitality Management, University of Rijeka, Croatia. She earned her master's degree (2007) and doctorate degree (2014) in economics at the University of Rijeka. Her main field of research are public finance and domestic and international taxation. She is an author or co-author of several works published in local and foreign scientific journals and presented at international conferences. Author can be contacted at sabinah@fthm.hr

Emira Bečić, Ph.D., works as a Senior Adviser at the Directorate for Science and Technology of the Ministry of Science, Education and Sports of the Republic of Croatia, mostly on the ERA policy and national reporting; economic growth and wellbeing. She earned her doctorate degree in economics at the University of Zagreb (2006). She is an author or co-author of more scientific articles and chapter in books in the field of sustainable development, regional foresight, smart specialization, science, research and economic growth. Author can be contacted at becic.emira@gmail.com 